\title{
PROGRAM PENANGGULANGAN BENCANA OLEH DISASTER MANAGEMENT CENTER (DMC) DOMPET DHUAFA
}

\author{
Oleh: \\ Azmi Sahid Fillah, Ishartono, \& Muhammad Fedryansyah \\ Email : \\ azmisahidfillah@gmail.com
}

\begin{abstract}
ABSTRAK
Masalah kebencanaan seakan tidak akan lepas dari bangsa Indonesia ini. Masalah kebencanaan di Indonesia menjadi permasalahan yang serius khususnya dalam penanggulangannya. Penanggulangan kebencanaan di Indonesia memang sudah berjalan dengan berbagai pelaksana,mulai dari lembaga pemerintahan maupun swasta yang khusus bergerak dalam penanggulangan bencana ini. Penanggulangan bencana menjadi perhatian khusus melihat banyaknya bencana yang terjadi di Indonesia ini baik itu yang disebabkan oleh alam maupun akibat dari ulah manusia itu sendiri. Konsep penanggulang bencana atau biasa disebut dengan manajemen bencana berkembang melihat dari dampak yang dihasilkan oleh bencana tersebut. Pada dasarnya konsep manajemen bencana ini adalah untuk mengurangi resiko ataupun dampak yang di rasakan dari adanya bencana. Cara bekerja manajemen bencana adalah melalui kegiatan-kegiatan yang ada pada tiap kuadran atau siklus atau bidang kerja yaitu pencegahan, mitigasi dan kesiapsiagaan, tanggap darurat, serta pemulihan. Sedangkan tujuannya secra umum antara lain untuk melindungi masyarakat beserta harta bendanya dari ancaman bencana. Tulisan ini mencoba menggambarkan konsep manajemen kebencanaan yang dilakukan oleh disaster management center Dompet Dhuafa (DMC DD). DMC DD sudah lama bergerak dalam kebencanaan. Tulisan ini mencoba mengulas bagaimana program manajemen bencana yang dilakukan oleh DMC DD berdasarkan teori menajemen bencana. Konsep atau teori tentang manajemen bencana akan menjadi dasar bagaimana program-program kebencanaanya.
\end{abstract}

\section{ABSTRACT}

Disaster problems seemed not to be separated from the nation of Indonesia. Disaster issues in Indonesia become a serious problem, especially in handling. Disaster prevention in Indonesia it is working with various executor, ranging from government and private institutions exclusively engaged in the response to this disaster. Disaster management is of particular concern at the number of disasters in Indonesia is whether it is caused by natural or the result of human activity itself. Penanggulang concept of disaster or commonly referred to as developing disaster management view of the impact generated by the disaster. Basically the concept of disaster management is to reduce the risk or impact on the feel of the disaster. Disaster management is a way to work through activities that exist in each quadrant or cycle or work areas, namely prevention, mitigation and preparedness, emergency response, and recovery. While the goal of a common secra among others, to protect the 
public and his possessions from the threat of disaster. This paper attempts to describe the concept of disaster management conducted by disaster management center Dompet Dhuafa (DMC DD). DD $D M C$ has long been engaged in disaster. This paper attempts to review how the disaster management program conducted by the DMC DD is based on the theory of disaster management. Concept or theory of disaster management will be the basis of how the programs described disaster

\section{Pendahuluan}

Fenomena bencana alam sangat erat sekali dengan bangsa Indonesia ini. Dengan kondisi geografisnya, Indonesia akan sangat sulit untuk lepas dari bencana. Bencana adalah peristiwa atau rangkaian peristiwa yang mengancam dan mengganggu kehidupan dan penghidupan masyarakat yang disebabkan oleh faktor alam dan atau faktor non alam termasuk manusia itu sendiri (karena konflik maupun teror) yang mengakibatkan timbulnya korban jiwa manusia, kerusakan lingkungan, kerugian harta benda dan dampak psikologis.

Terkait dengan dampak dari bencana alam, dibutuhkan penanggulangan bencana baik itu pra bencana atau (mitigasi bencana), bencana, maupun pasca bencana. Sesuai dengan UU 24/2007, Penanggulangan bencana adalah serangkaian upaya yang meliputi penetapan kebijakan pembangunan yang beresiko timbulnya bencana, kegiatan pencegahan bencana, tanggap darurat, rehabilitasi dan rekonstruksi. Ketiga upaya tersebut masing-masing memiliki fungsi dan tujuan terkait dengan penanggulangan bencana alam dan ketiga proses penanggulangan tersebut juga sangat penting dalam menghadapi bencana alam.

Masalah yang ada, dalam pelaksanaannya adalah program-program penanggulangan terkadang hanya dalam program tanggap darurat semata. Program penanggulangan bencana baik itu pra dan pasca kurang diperhatikan oleh lembagalembaga pelayanan kebencanaan. Akibatnya dampak yang terjadi akibat bencana akan lebih berat dan sulit dalam proses rehabilitasi fisik maupun rehabilitasi dari korban bencana itu sendiri. Padahal tahap pra bencana dan pasca bencana juga sangat penting dalam penanggulangan bencana alam. Pra bencana menitik beratkan kepada proses pencegahan agar mengurangi risiko bencana melalui upaya sistematis untuk menganalisa dan mengurangi faktor-faktor penyebab bencana. Sedangkan dalam pasca bencana menitik beratkan kepada rehabilitasi dan rekonstruksi.

Masalah lainnya adalah, walaupun tahap pasca bencana tetap dilakukan, tetapi dalam pelasanaanya tidak tepat. Akibatnya dalam proses rahabilitasi fisik maupun korban tidak berjalan dengan baik. Pada dasarnya, bencana alam secara langsung akan menimbulkan dampak kepada masyarakat, baik itu dalam infrastruktur maupun dampak psikologis korban bencana. Hal ini akan berdampak kepada proses pemulihan trauma dari korban bencana akan lambat.

Dalam masalah penanggulangan bencana alam, sejak Sejak tahun 2001, Pemerintah Indonesia telah memiliki kelembagaan penanggulangan bencana seperti tertuang dalam Keputusan Presiden Nomor 3 Tahun 2001 tentang Badan Koordinasi Nasional Penanggulangan Bencana dan Penanganan Pengungsi sebagaimana telah diubah dengan Keputusan Presiden Nomor 111 Tahun 2001. Selanjutnya Bakornas-PB digantikan menjadi BNPB sesuai dengan UU No. 24 tahun 2007 tentang Penanggulangan Bencana. Hal inilah yang mempelopori lembaga-lembaga lain yang bergerak dalam kebencanaan. Salah satuntnya adalah Disaster Management Center Dompet Dhuafa.

Timbulnya kesadaran akan pentingnya penanggulangan kebencanaan baik itu pra, 
tanggap bencana, maupun pasca bencana pada dasarnya karena kondisi Indonesia terkait dengan bencana. Melihat seringnya bencana di tanah Indonesia ini membuat Indoensia tergolong sebagai Negara dengan rawan bencana. Terlihst juga bahwa kerentanan masyarakat akan dampak bencana yang sangat tinggi meneyebabkan timbulnya kesadaran akan pentingnya penanggulangan bencana dengan baik dan benar.

Pada dasarnya bencana alam dapat terjadi secara tiba-tiba maupun melalui proses yang berlangsung secara perlahan. Beberapa jenis bencana seperti gempa bumi, hampir tidak mungkin diperkirakan secara akurat kapan, di mana akan terjadi dan besaran kekuatannya. Sedangkan beberapa bencana lainnya seperti banjir, tanah longsor, kekeringan, letusan gunung berapi, tsunami dan anomali cuaca masih dapat diramalkan sebelumnya. Meskipun demikian kejadian bencana selalu memberikan dampak kejutan dan menimbulkan banyak kerugian baik jiwa maupun materi. Kejutan tersebut terjadi karena kurangnya kewaspadaan dan kesiapan dalam menghadapi ancaman bahaya.

UU No. 24 tahun 2007 mendefinisikan bencana sebagai peristiwa atau rangkaian peristiwa yang mengancam dan mengganggu kehidupan dan penghidupan masyarakat yang disebabkan, baik oleh faktor alam dan/atau faktor non alam maupun faktor manusia sehingga mengakibatkan timbulnya korban jiwa manusia, kerusakan lingkungan, kerugian harta benda, dan dampak psikologis. Sementara Asian Disaster Preparedness Center (ADPC) mendefinisikan bencana dalam formulasi sebagai berikut

The serious disruption of the functioning of society, causing widespread human, material or environmental losses, which exceed the ability of the affected communities to cope using their own resources (Abarquez \& Murshed, 2004).

Dari banyaknya pengamatan akan bencana, maka dapat ditemukan karakteristik dari bencana itu sendiri sebagai berikut (Royan, 2004):

1. Terdapat kerusakan pada pola kehidupan normal. Kerusakan tersebut biasanya terlihat cukup parah, sebagai akibat dari kejadian yang mendadak dan tidak terduga serta luasnya cakupan akan dampak dari bencana.

2. Dampak dari bencana merugikan manusia, baik bersifat langsung maupun tidak. Biasanya dapat berupa kematian, kesakitan, kesengsaraan, maupun akibat negatif lainnya yang berdampak pada kesehatan masyarakat.

3. Merugikan struktur sosial, seperti kerusakan pada sistem pemerintahan, bangunan, komunikasi, dan berbagai sarana dan prasarana pelayanan umum lainnya.

4. Adanya pengungsian yang membutuhkan tempat tinggal atau penampungan, makanan, pakaian, bantuan kesehatan, dan pelayanan sosial. Yang terkadang tidak mencukupi atau kurang terkoordinasi.

Dengan ditetapkannya Undang-undang Nomor 24 Tahun 2007 tentang Penanggulangan Bencana, maka penyelenggaraan penanggulangan bencana diharapkan akan semakin efektif, karena Pemerintah dan Pemerintah daerah menjadi penanggung jawab dalam penyelenggaraan penanggulangan bencana. Penanggulangan bencana dilakukan secara terarah mulai pra-bencana, saat tanggap darurat, dan pasca bencana. Tahap awal dalam upaya ini adalah mengenali/mengidentifikasi terhadap sumber bahaya atau ancaman bencana.

Terkait dengan penanggulangan bencana, melihat banyaknya peristiwa bencana yang terjadi dan menimbulkan korban jiwa serta kerugian harta benda yang besar di Indonesia, mengindikasikan bahwa manajemen bencana di negara Indonesia masih jauh dari yang diharapkan. Selama ini, manajemen bencana dianggap bukan prioritas dan hanya datang sewaktuwaktu saja, padahal 
kita hidup di wilayah yang rawan terhadap ancaman bencana. Oleh karena itu pemahaman terhadap manajemen bencana pelu dimengerti dan dikuasi oleh seluruh kalangan, baik pemerintah, masyarakat, maupun swasta.

Manajemen bencana menurut Nurjanah (2012:42) adalah ilmu pengetahuan yang mempelajari bencana beserta segala aspek yang berkaitan dengan bencana, terutama risiko bencana dan bagaimana menghindari risiko bencana. Manajemen bencana merupakan proses dinamis tentang bekerjanya fungsi-fungsi manajemen yang kita kenal selama ini misalnya fungsi planning, organizing, actuating, dan controling. Cara bekerja manajemen bencana adalah melalui kegiatan-kegiatan yang ada pada tiap kuadran atau siklus atau bidang kerja yaitu pencegahan, mitigasi dan kesiapsiagaan, tanggap darurat, serta pemulihan. Sedangkan tujuannya secra umum antara lain untuk melindungi masyarakat beserta harta bendanya dari ancaman bencana.

Adapun proses manajemen bencana adalah sebagai beriku.

Menurut Nurjanah (2012:47), secara umum kegiatan manajemen bencana dapat dibagi dalam tiga kegiatan utama, yaitu:

1. Kegiatan pra bencana yang mencakup kegiatan pencegahan, mitigasi, kesiapsiagaan, serta peringatan dini.

Kegiatan pada tahap pra bencana ini sangat penting karena apa yang sudah dipersiapkan pada tahap ini merupakan modal dalam menghadapi bencana dan pasca bencana. Pemerintah bersama masyarakat maupun swasta sangat sedikit memikirkan tentang langkah-langkah atau kegiatan-kegiatan apa yang perlu dilakukan di dalam menghadapi bencana atau bagaimana memperkecil dampak bencana.

2. Kegiatan saat terjadi bencana yang mencakup kegiatan tanggap darurat untuk meringankan penderitaan sementara, seperti search and rescue (SAR), bantuan daruirat dan pengungsian.
Kegiatan saat terjadi bencana yang dilakukan segera pada saat kejadian bencana. Untuk menanggulangi dampak yang ditimbulkan, terutama berupa penyelamatan korban dan harta benda, evakuasi dan pengungsian, akan mendapatkan perhatian penuh baik dari pemerintah bersama swasta maupun masyarakatnya. Pada saat terjadimya bencana biasanay banyak pihak yang menaruh perhatian dan mengulurkan tangan memberikan bantuan tenaga, moril maupun material. Banyaknya bantuan yang datang sebenarnya merupakan sebuah keuntungan yang harus dikelola dengan baik, agar setiap bantuan yang masuk dapat tepat guna, tepat sasaran, tepat manfaat, dan efisien.

3. Kegiatan pasca bencana yang mencakup kegiatan pemulihan, rehabilitasi, dan rekonstruksi.

Kegiatan pada tahap pasca bencana, terjadi proses perbaikian kondisi masyarakat yang tekena bencana, dengan memfungsikan kembali prasarana 16 dan sarana pada keadaan semula. Pada tahap ini yang perlu diperhatikan adalah bahwa rehabilitasi dan rekonstruksi yang akan dilaksanakan harus memenuhi kaidahkaidah kebencanaan serta tidak hanya melakukan rehabilitasi fisik saja, tetapi perlu juga diperhatikan rehabilitasi psikis yang tejadi seperti ketakutan, trauma atau depresi.

\section{Metode Penelitian}

Metode yang digunakan dalam penulisan karya tulis ini adalah metode penelitian deskriptif. Metode yang digunakan untuk pengumpulan data adalah metode studi pustaka yang terdiri atas pencarian datadan informasi melalui dokumen-dokumen pendukung berupa data dai buku, jurnal ilmiah, dan dokumen elektronik dari internet. Adapun 
tahapan dalam penulisan diantaranya perumusan masalah untuk kemudian menjadi gagasan, pengumpulan data dan fakta terkait, verifikasi data dan fakta, analisakonseptual, perumusan hasil gagasan dan kesimpulan serta rekomendasi terkait penanganan masalah.

Hasil dan pembahasan

Bencana dan Manajemen Bencana

Bencana alam, dipandang sebagai peristiwa atau rangkaian peristiwa yang mengancam dan mengganggu kehidupan dan penghidupan masyarakat yang disebabkan, baik oleh faktor alam dan/atau faktor non alam maupun faktor manusia sehingga mengakibatkan timbulnya korban jiwa manusia, kerusakan lingkungan, kerugian harta benda, dan dampak psikologis. Jika ditinjau dari penyebabnya dapat dibagi menjadi tiga jenis yaitu: bencana alam geologis, klimatologis, dan ekstra-terestrial (Buletin KAMADHIS UGM. 2007:3). Bencana alam geologis adalah bencana alam yang disebabkan oleh gaya-gaya dari dalam bumi. Sedangkan bencana alam klimatologis adalah bencana alam yang disebabkan oleh perubahan iklim, suhu atau cuaca. Bencana alam ekstra-terestrial yaitu bencana alam yang disebabkan oleh gaya atau energi dari luar bumi, bencana alam geologis dan klimatologis yang sering berdampak terhadap manusia.

Terkait hal tersebut, factor penyebab bencana dapat diuraikan sebagai berikut. Bencana dapat disebabkan oleh kejadian alam (natural disaster) maupun oleh ulah manusia (man-made disaster). Faktor-faktor yang dapat menyebabkan bencana antara lain (Bappenas, 2006):

a. Bahaya alam (natural hazards) dan bahaya karena ulah manusia (man-madehazards) yang menurut United Nations International Strategy for DisasterReduction (UN-ISDR) dapat dikelompokkan menjadi bahaya geologi (geological hazards), bahaya hidrometeorologi (hydrometeorological hazards), bahaya biologi (biological hazards), bahaya teknologi (technological hazards) dan penurunan kualitas lingkungan (environmental degradation).

b. Kerentanan (vulnerability) yang tinggi dari masyarakat, infrastruktur serta elemen-elemen di dalam kota/ kawasan yang berisiko bencana.

c. Kapasitas yang rendah dari berbagai komponen di dalam masyarakat.

Fase-Fase Bencana

Menurut Santamaria (1995) bencana terjadi melalui tiga fase yaitu pre-impact (pradampak), impact (dampak), dan post-impact

a. Fase pra-dampak (pre-impact) merupakan fase peringatan (warning phase) yaitu tahap awal adanya bencana. Informasi diperoleh dari badan satelit dan meteorologi cuaca, atau lembaga lain yang bertanggung jawab terjadinya bencana .

b. Fase dampak merupakan fase terjadinya bencana. Pada fase inilah manusia berusaha semaksimal mungkin mencari pertolongan untuk menyelamatkan diri, keluarga, atau harta benda agar dapat bertahan hidup (survive). Fase ini terus berlanjut hingga mengakibatkan kerusakan dan mendapatkan bantuanbantuan darurat.

c. Fase pasca dampak dimulai saat pemulihan dari fase darurat. Fase ini juga ditandai dengan dimulainya masyarakat berusaha kembali melakukan aktifitas secara normal. Secara umum dalam pasca dampak ini para korban bencana akan mengalami dampak psikologis berupa penolakan, marah, tawar menawar, depresi hingga akhirnya bisa menerima (relokasi), maka di tempat baru mereka memasuki fase pasca 
dampak, bukan saat berada dalam pengungsian.

Sementara untuk peristiwa bencana yang bersifat emergensi atau gawat darurat, kelompok kerja UNICEF dan Pusat Studi Pengembangan Integratif Universitas Filipina membagi intervensi penanggulangan bencana berdasarkan fase-fase sebagai berikut:

a. Fase segera setelah kejadian (rescue)

b. Fase pemulihan awal (bulan pertama setelah kejadian):

c. Fase pemulihan lanjutan (dua bulan setelah kejadian dan setelahnya):

d. Fase rekonstruksi

\section{Dampak Bencana Alam}

Membahas mengenai kebencanaan, tidak akan lepas akan mengenai dampak yang ditimulkan oleh bencana itu sendiri. Damapak dari bencana yang terjadi sangatlah beragam, mulai dari dampak psikologis, fisik, maupun infrastruktur. Oleh karena itu dapat dikatakan bahwa bencana alam dapat mengakibatkan dampak yang merusak pada bidang ekonomi, sosial dan lingkungan. Kerusakan infrastruktur dapat mengganggu aktivitas sosial, dampak dalam bidang sosial mencakup kematian, lukaluka, sakit, hilangnya tempat tinggal dan kekacauan komunitas, sementara kerusakan lingkungan

Dampak yang dihasilkan tergantung pada kemampuan untuk mencegah atau menghindari bencana dan daya tahan mereka. Pemahaman ini berhubungan dengan pernyataan: "bencana muncul bila ancaman bahaya bertemu dengan ketidakberdayaan". Dengan demikian, aktivitas alam yang berbahaya tidak akan menjadi bencana alam di daerah tanpa ketidakberdayaan manusia, misalnya gempa bumi di wilayah tak berpenghuni. Konsekuensinya, pemakaian istilah "alam" juga ditentang karena peristiwa tersebut bukan hanya bahaya atau malapetaka tanpa keterlibatan manusia. Besarnya potensi kerugian juga tergantung pada bentuk bahayanya sendiri, mulai dari kebakaran, yang mengancam bangunan individual, sampai peristiwa tubrukan meteor besar yang berpotensi mengakhiri peradaban umat manusia. Namun demikian pada daerah yang memiliki tingkat bahaya tinggi (hazard) serta memiliki kerentanan/kerawanan(vulnerability) yang juga tinggi tidak akan memberi dampak yang hebat/luas jika manusia yang berada disana memiliki ketahanan terhadap bencana (disaster resilience). Konsep ketahanan bencana merupakan valuasi kemampuan sistem dan infrastruktur-infrastruktur untuk mendeteksi, mencegah \& menangani tantangan-tantangan serius yang hadir. Dengan demikian meskipun daerah tersebut rawan bencana dengan jumlah penduduk yang besar jika diimbangi dengan ketetahanan terhadap bencana yang cukup.

\section{Manajemen Bencana.}

Dalam Konsep manajeman bencana, kegiatan manajemen bencana merupakan kegiatan yang tidak berdiri sendiri, akan tetapi terkait dengan berbagai aspek kehidupan masyarakat dan memerlukan pendekatan yang bersifat multidisiplin. Peraturan perundang-undangan yang dijadikan acuan pun melingkup peraturan perundang-undangan lintas sektor. Dengan kalimat lain, sesungguhnya kegiatan manajemen bencana dilaksanakan oleh sektorsektor, sedangkan kegiatan dari lembaga kebencanaan sebagian besar adalah mengkoordinasikan kegiatan yang dilakukan oleh sektor.

Berbagai pihak yang terlibat dalam manajemen bencana harus saling bekerjasama dan menyamakan persepsi tentang bencana dan manajemen bencana melalui sebuah sistem atau aturan main yang disepakati taiu sistem manajemen bencana. Melalui manajemen bencana pula program atau kegiatan dilaksanakan pada tiap kuadran atau siklus atau bidang erja oleh para pemangku kepentingan secara komprehensif dan terusmenerus. Pelaksanan kegiatan secara periodi atau sebagai reaksi atau respon terhadap 
kejadian bencana akan menjadi sia-sia karena bencana akan terus terjadi secara berulang. Sehingga dapat disimpulkan bahwa, manajemen bencana sebagai seluruh kegiatan yang meliputi aspek perencanaan dan penanggulangan bencana, pada sebelum, saat dan sesudah terjadi bencana yang dilakukan oleh semua elemen, pemerintah, masyarakat sipil, dan kalangan bisnis-korporasi untuk mencegah kehilangan jiwa, mengurangi penderitaan manusia, memberi informasi kepada masyarakat dan pihak berwenang mengenai risiko, dan mengurangi kerusakan infrastruktur utama, harta benda dan kehilangan sumber ekonomis.

Terkait dengan hal tersebut, DMC DD mempunyai program-program terkait dengan kebencananaan. Program-program DMC DDterkait dengan manajemen bencana penulis mencoba menjelaskan program-program tersebut berdasarkan proses manajemen bencana yang sudah penulis jabarkan sebelumnya.

Sekilas mengenai DMC DD, Disaster Management Center Dompet Dhuafa adalah sebuah lembaga garda terdepan dalam pengelolaan kebencanaan. Sebagai bagian dari Dompet Dhuafa yang telah beraktivitas sejak tahun 1994. Pada tanggal 25 Maret 2010 DMC Dompet Dhuafa secara resmi berdiri.

Terkait dengan manajemen bencana, proses respon terhadap bancana DMC DD membaginya menjadi 2 tahap. Yang pertama adalah Siklus Tanggap Darurat dan Siklus Recovery.

\section{Sikulus Tanggap Darurat}

Pada siklus tanggap darurat bencana adalah serangkaian kegiatan yang dilakukan dengan segera pada saat kejadian bencana untuk menangani dampak buruk yang ditimbulkan, yang meliputi kegiatan penyelamatan dan evakuasi korban, harta benda, pemenuhan kebutuhan dasar, perlindungan, pengurusan pengungsi, penyelamatan, serta pemulihan prasarana dan sarana.

Tahapan pelaksanaan pada fase tanggap darurat tim DMC Dompet Dhuafa, meliputi: pengkajian secara cepat dan tepat terhadap lokasi, kerusakan, kerugian, dan sumber daya; penentuan status keadaan darurat bencana; penyelamatan dan evakuasi masyarakat terkena bencana; pemenuhan kebutuhan dasar; perlindungan terhadap kelompok rentan; dan pemulihan dengan segera prasarana dan sarana vital.

\section{Siklus Recovery}

Pada siklus Recovery kegiatan meliputi rehabilitasi dan rekonstruksi. Rehabilitasi adalah perbaikan dan pemulihan semua aspek pelayanan publik atau masyarakat sampai tingkat yang memadai pada wilayah pascabencana dengan sasaran utama untuk normalisasi atau berjalannya secara wajar semua aspek pemerintahan dan kehidupan masyarakat pada wilayah pascabencana. Rekonstruksi adalah pembangunan kembali semua prasarana dan sarana, kelembagaan pada wilayah pascabencana, baik pada tingkat pemerintahan maupun masyarakat dengan sasaran utama tumbuh dan berkembangnya kegiatan perekonomian, sosial dan budaya, tegaknya hukum dan ketertiban, dan bangkitnya peran serta masyarakat dalam segala aspek kehidupan bermasyarakat pada wilayah pasca bencana.

Mengacu kepada tiga hal yang mutlak dilakukan dama manajeman bencana, DMC DD juga melakukan proses penanggulangan pra bencana. Pra bencana yang dilakukan mencakup kegiatan pencegahan, mitigasi, kesiapsiagaan, serta peringatan dini;

1. Pencegahan (prevension); upaya untuk menghilangkan atau mengurangi kemungkinan timbulnya suatu ancaman. Misalnya : pembuatan bendungan untuk menghindari terjadinya banjir, biopori, penanaman tanaman keras di lereng bukit untuk menghindari banjir dsb. Namun perlu disadari bahwa pencegahan tidak bisa $100 \%$ efektif terhadap sebagian besar bencana.

2. Mitigasi (mitigation); yaitu upaya yang dilakukan untuk mengurangi dampak buruk dari suatu ancaman. Misalnya : 
penataan kembali lahan desa agar terjadinya banjir tidak menimbulkan kerugian besar.

3. Kesiap-siagaan (preparedness); yaitu persiapan rencana untuk bertindak ketika terjadi(atau kemungkinan akan terjadi) bencana. Perencanaan terdiri dari perkiraan terhadap kebutuhan-kebutuhan dalam keadaan darurat danidentifikasi atas sumber daya yang ada untuk memenuhi kebutuhan tersebut. Perencanaan ini dapat mengurangi dampak buruk dari suatu ancaman.

\section{KESIMPULAN}

Melalui konsep berpikir ini dapat menggambarkan proses pelayanan terkait kebencanan yang dilakukan oleh DMC DD. Sehingga dalam penanggulangannya dapat berjalan dengan baik. Sehingga dapat meminimalisir dampak yang dirasakan.

Pada dasarnya semua proses manajemen akan sangat penting dilakukan terkait dalam penanggulangan bencana. Masalah selama ini adalah tidak banyak lembaga yang bergerak penanggulangan bencana yang melakukan semua proses manajemen bencana. Karena memang semua proses manajemen bencana mempunyai fungsi dan tujuan yang berbedabeda.

1. Kegiatan pra bencana yang mencakup kegiatan pencegahan, mitigasi, kesiapsiagaan, serta peringatan dini.

Kegiatan pada tahap pra bencana ini sangat penting karena apa yang sudah dipersiapkan pada tahap ini merupakan modal dalam menghadapi bencana dan pasca bencana. Pemerintah bersama masyarakat maupun swasta sangat sedikit memikirkan tentang langkah-langkah atau kegiatan-kegiatan apa yang perlu dilakukan di dalam menghadapi bencana atau bagaimana memperkecil dampak bencana.

2. Kegiatan saat terjadi bencana yang mencakup kegiatan tanggap darurat untuk meringankan penderitaan sementara, seperti search and rescue (SAR), bantuan daruirat dan pengungsian.

Kegiatan saat terjadi bencana yang dilakukan segera pada saat kejadian bencana. Untuk menanggulangi dampak yang ditimbulkan , terutama berupa penyelamatan korban dan harta benda, evakuasi dan pengungsian, akan mendapatkan perhatian penuh baik dari pemerintah bersama swasta maupun masyarakatnya. Pada saat terjadimya bencana biasanay banyak pihak yang menaruh perhatian dan mengulurkan tangan memberikan bantuan tenaga, moril maupun material. Banyaknya bantuan yang datang sebenarnya merupakan sebuah keuntungan yang harus dikelola dengan baik, agar setiap bantuan yang masuk dapat tepat guna, tepat sasaran, tepat manfaat, dan efisien.

3. Kegiatan pasca bencana yang mencakup kegiatan pemulihan, rehabilitasi, dan rekonstruksi.

Kegiatan pada tahap pasca bencana, terjadi proses perbaikian kondisi masyarakat yang tekena bencana, dengan memfungsikan kembali prasarana 16 dan sarana pada keadaan semula. Pada tahap ini yang perlu diperhatikan adalah bahwa rehabilitasi dan rekonstruksi yang akan dilaksanakan harus memenuhi kaidahkaidah kebencanaan serta tidak hanya melakukan rehabilitasi fisik saja, tetapi perlu juga diperhatikan rehabilitasi psikis yang tejadi seperti ketakutan, trauma atau depresi.

Daftar Pustaka

BAKORNAS Penanggulangan Bencana. Rencana Nasional Penangulangan Bencana. 2010-2014

Bakornas PBP (2005), Panduan Pengenalan Karakteristik Bencana dan Upaya 
Migitasinya di Indonesia, SatBakornas PBP, Jakarta.

Badan Nasional Penanggulangan Bencana (2008), Pedoman Penyusunan Rencana Penanggulangan Bencana, Peraturan Kepala Badan Nasional Penanggulangan Bencana Nomor 4 Tahun 2008, BNPB, Jakarta.
Coburn, A. W, et.al (1994), Modul Mitigasi Bencana, UNDP, United Kingdom

Bakornas PBP (2005), Panduan Pengenalan Karakteristik Bencana dan Upaya Migitasinya di Indonesia, SatBakornas PBP, Jakarta. 